\title{
Normal Regulation of Calcitriol Production in Gy Mice \\ Evidence for Biochemical Heterogeneity in the X-linked Hypophosphatemic Diseases
}

Giora A. Davidai, Teresa Nesbitt, and Marc K. Drezner

Departments of Medicine and Physiology, Duke University Medical Center, Durham, North Carolina 27710

\begin{abstract}
Phenotypic heterogeneity in $\mathrm{X}$-linked hypophosphatemic rickets (XLH) is ascribed to variable penetrance of the genetic abnormality. However, studies of hypophosphatemic ( $\mathrm{Hyp})$ and gyrorotary $(G y)$ mice indicate that mutations at different loci along the $\mathbf{X}$ chromosome may underlie the genetically transmitted hypophosphatemic disorders. Thus, genetic heterogeneity may be a determinant of the phenotypic variability in XLH. To determine if such variance includes biochemical diversity, we examined whether $G y$ mice, similar to $H y p$ mice, exhibit abnormal regulation of renal 25-hydroxyvitamin D (25[OH]D)-1 $\alpha$-hydroxylase. Serum phosphorus in $G y$ $(4.7 \pm 0.3 \mathrm{mg} / \mathrm{dl})$ and phosphate $(\mathrm{P})$-depleted mice $(4.9 \pm 0.4)$ was significantly less than normal $(8.4 \pm 0.5)$. Consistent with $P$ depletion, the $G y$ mice exhibited enhanced renal 25(OH)D$1 \alpha$-hydroxylase activity $(9.3 \pm 0.6 \mathrm{fmol} / \mathrm{mg}$ kidney per $\mathrm{min})$, similar to that of P-depleted normals $(9.1 \pm 1.5)$, but significantly greater than that of controls $(3.1 \pm 0.3)$. Such normal enzyme responsiveness was confirmed upon PTH stimulation (1 IU/h s.c.), which revealed that $G y$ mice increased renal 1-hydroxylase $(59 \pm 7.7)$ similarly to normals $(65 \pm 7.7)$ and $P$ depleted animals (58.4 \pm 7.8$)$. Calcitonin administration also enhanced enzyme function comparably in the animal models. Evidence confirming normally responsive calcitriol production in untreated $G y$ mice included increased serum 1,25-dihydroxyvitamin D levels, gastrointestinal calcium absorption, and urinary calcium. The normally regulated vitamin D metabolism in $G y$ mice indicates that biochemically diverse disease may result from mutations in the gene family regulating renal $P$ transport and underlying $X$-linked hypophosphatemia. We suspect such heterogeneity is due to altered $P$ transport at variable segments of the proximal convoluted tubule. (J. Clin. Invest. 1990. 85:334-339.) calcitriol • hypophosphatemia • rickets
\end{abstract}

\section{Introduction}

X-linked hypophosphatemic rickets/osteomalacia $(\mathrm{XLH})^{1}$ is the prototypic form of vitamin D-resistant disease in man.

Portions of this work have appeared in abstract form (1988. J. Bone Miner. Res. 3 [suppl]:S92).

Address reprint requests to Dr. Marc Drezner, Box 3285, Duke University Medical Center, Durham, NC 27710.

Received for publication 10 January 1989 and in revised form 12 September 1989

1. Abbreviations used in this paper: Gy, gyrorotary; Hyp, hypophosphatemic; i, immunoreactive; $25(\mathrm{OH}) \mathrm{D}, 25$-hydroxyvitamin $\mathrm{D}$;

J. Clin. Invest.

(c) The American Society for Clinical Investigation, Inc. 0021-9738/90/02/0334/06 \$2.00

Volume 85, February 1990, 334-339
Since its initial description in 1937 (1), a remarkable phenotypic heterogeneity has been observed in patients with this disorder (2-5). In general, such heterogeneity has been ascribed to variable penetrance of the genetic abnormality (6-8). However, recent studies of hypophosphatemic ( $\mathrm{Hyp})$ and gyrorotany $(G y)$ mice, murine homologues of the human disease, indicate that mutations at two distinctly different loci along the $\mathrm{X}$ chromosome, which regulate renal phosphate transport, may underlie genetically transmitted hypophosphatemic disorders (9). Accordingly, genetic heterogeneity may be an additional determinant of the phenotypic variability characteristic of XLH.

Whether such genetically determined variance includes biochemical diversity, however, remains unknown. Preliminary studies by Lyon et al. (9) indicate that $H y p$ and $G y$ mice, in fact, share similar abnormalities, such as hypophosphatemia and renal phosphate wasting. However, these investigations did not include examination of many of the classic biochemical defects characteristic of XLH. In this regard, previous work has established that $H y p$ mice exhibit abnormal phosphate/PTH regulation of renal 25-hydroxyvitamin D (25[OH]D)-1 $\alpha$-hydroxylase activity (10-13). Thus, in the present study we tested for the presence of genetically determined biochemical heterogeneity by examining if $G y$ mice exhibit disparately regulated calcitriol production. Our discovery that Gy mice display normally regulated vitamin D metabolism suggests that biochemically diverse hypophosphatemic disorders may result from mutations in a gene family regulating renal phosphate transport.

\section{Methods}

\section{Animals}

Normal $\mathrm{B}_{6} \mathrm{C}_{3} \mathrm{H}$ male mice and $\mathrm{B}_{6} \mathrm{C}_{3} \mathrm{H}$ heterozygous female $G y$ mice obtained from the Jackson Animal Laboratories (Bar Harbor, ME) were mated, and male and female weanling $G y$ mice obtained from the resultant litters were identified by their characteristic phenotypic appearance and their serum phosphorus level (9) at 4-5 wk of age. $G y$ mice of both sexes were used in our investigation since we found that the biochemical expression of the $G y$ mutation is present to an almost identical extent in females, despite the X-linked dominance of the disorder. An equal number of male and female normal littermates were also chosen. All animals received an appropriate diet (as described below) and deionized water ad lib until study 4-5 wk later.

\section{Experimental protocols}

RENAL $25(\mathrm{OH}) \mathrm{D}-1 \alpha$-HYDROXYLASE ACTIVITY IN NORMAL, GY, AND PHOSPHATE (P)-DEPLETED MICE

Basal function. In our initial investigations we assessed renal $25(\mathrm{OH}) \mathrm{D}-1 \alpha$-hydroxylase activity in age-matched normal and $G y$ mice fed a diet containing $0.6 \%$ calcium and $0.6 \%$ phosphorus (Teklad

$25(\mathrm{OH}) \mathrm{D}_{3}, 25$-hydroxyvitamin $\mathrm{D}_{3} ; 1,25(\mathrm{OH})_{2} \mathrm{D}, 1,25$-dihydroxyvitamin D; PCT, proximal convoluted tubule; P-depleted, phosphorusdepleted; $U_{c a}$, urine calcium; $U_{c r}$, urine creatine; $X L H, X$-linked hypophosphatemic rickets/osteomalacia. 
Co., Madison, WI), and P-depleted normal mice given an otherwise identical ration with $0.02 \%$ inorganic phosphorus for $3 \mathrm{wk}$ before study. At the time of experiments mice (6-8 wk of age) were exsanguinated and dispatched, and the kidneys were excised for measurement of enzyme activity. Serum calcium, inorganic phosphorus, immunoreactive (i) PTH, and 1,25-dihydroxyvitamin D $\left(1,25[\mathrm{OH}]_{2} \mathrm{D}\right)$ were determined for all groups.

$P T H$ effects. In subsequent investigations we examined the effect of PTH on renal $25(\mathrm{OH}) \mathrm{D}-1 \alpha$-hydroxylase activity in the normal, $G y$, and P-depleted normal mice. To control the uniformity of the applied stimulus, we used surgically implantable Alzet osmotic minipumps (model 2001; Alza Corp., Palo Alto, CA) for continuous subcutaneous infusion of PTH. Bovine parathyroid extract $(285 \mathrm{U} / \mathrm{mg}$, Sigma Chemical Co., St. Louis, MO) was dissolved in physiologic saline $(0.9 \%$ $\mathrm{NaCl}$ ) containing $20 \mathrm{mg} / \mathrm{ml}$ cysteine hydrochloride. Minipumps were filled with the PTH solution (1 IU/ $\mu \mathrm{l}$ ) and immersed in saline for $24 \mathrm{~h}$ before implantation to allow for equilibration of pump flow rate. After sodium pentobarbital anesthesia $(65 \mathrm{mg} / \mathrm{kg}$ i.p.) the minipumps were implanted subcutaneously in each of the groups through a small skin incision in the dorsal lumbar region. The incision was closed with a wound clip. In several experiments we determined that in normal, $G y$, and P-depleted mice anesthesia, sham operation, and infusion of vehicle (saline or saline containing cysteine hydrochloride $[20 \mathrm{mg} / \mathrm{ml}]$ ) via an osmotic minipump for $24 \mathrm{~h}$ did not alter the renal 25(OH)D- $\alpha$-hydroxylase activity (e.g., $4 \pm 0.74$ [untreated normals], $4.2 \pm 0.76$ [shamoperated, saline-infused normals], and $3.2 \pm 0.50$ [sham-operated, saline/cysteine hydrochloride-infused normals] fmol/mg kidney per min) or the serum calcium or phosphorus concentration. Therefore, controls in individual experiments were not routinely subjected to anesthesia and sham operation. After $24 \mathrm{~h}$ the mice were exsanguinated and dispatched, and their kidneys were excised for measurement of 1-hydroxylase activity. Serum calcium and inorganic phosphorus were determined for all groups.

Calcitonin effects. In similar studies we investigated the influence of calcitonin on renal $25(\mathrm{OH}) \mathrm{D}-1 \alpha$-hydroxylase activity in the normal, $G y$, and P-depleted mice. Human synthetic calcitonin $(3,000 \mathrm{IU} / \mathrm{mg}$, Sigma Chemical $\mathrm{Co}$.) in $0.9 \% \mathrm{NaCl}$ was administered to the animals via osmotic minipumps (as described above) at a rate of $2 \mathrm{IU} / \mu \mathrm{l}$. After $24 \mathrm{~h}$ treated mice and appropriate controls were bled for serum biochemical determinations and kidneys were removed for assay of $1 \alpha$ hydroxylase activity.

CALCIUM HOMEOSTASIS IN NORMAL, GY, AND P-DEPLETED MICE

Gastrointestinal calcium absorption. To assess the physiologic effects of $1,25(\mathrm{OH})_{2} \mathrm{D}$ in the normal, $G y$, and P-depleted mice we measured the gastrointestinal calcium absorption. We determined this variable using an in situ loop technique (14) modified for the mouse. Nonfasted mice were anesthetized and a longitudinal incision made to expose the small intestine. The duodenal segment was ligated at the pylorus and $3-5 \mathrm{~cm}$ distally at the ligament of Treitz. The loop was filled with a test solution $(0.07-0.10 \mathrm{ml})$ containing $90 \mathrm{mM}$ calcium and the abdominal incision was closed. After $60 \mathrm{~min}$ the loop was removed and the entire loop and its contents were homogenized in $1 \mathrm{ml}$ of deionized water. The resulting homogenate was divided into two equal parts that were used to measure calcium (15) and protein content (16), respectively. We calculated the calcium absorption per milligram of protein since the protein content correlated well with the varying duodenal loop size in the groups examined. The amount of calcium absorbed from each loop was determined by the equation, calcium instilled + tissue calcium - calcium recovered in whole loop homogenate $=$ calcium absorbed from the loop (milligrams/milligram protein). We determined tissue calcium content in the duodenal segments of appropriate controls.

Urinary calcium excretion. In subsequent studies we measured urinary calcium excretion in normal, $G y$, and P-depleted mice. In ageand sex-matched groups of five mice, spontaneously voided urine was collected three times daily. This procedure was repeated five times, $4 \mathrm{~d}$ apart, and urine obtained from each group on a single test day was pooled to provide adequate volume for the measurements. Data are expressed as milligrams urine calcium $\left(U_{\mathrm{ca}}\right)$ /milligrams urine creatinine $\left(U_{\text {cr }}\right)$.

\section{Analytical methodology}

In vitro assay of murine renal 25(OH)D-l $\alpha$-hydroxylase activity. We measured the maximum velocity of $1 \alpha$-hydroxylase in kidney homogenates by our previously described method (17). The assay used $(a)$ sufficient nonradioactive 25 -hydroxyvitamin $\mathrm{D}_{3}\left(25[\mathrm{OH}] \mathrm{D}_{3}\right)$ to maintain an optimal concentration for 1-hydroxylation (17) while saturating the inhibitory factor present in mammalian renal homogenates (17); (b) a sample purification scheme consisting of chloroform/methanol (1:2) extraction of kidney homogenates, Sephadex LH-20 chromatography of lipid extract, and HPLC (hexane/2-propanol, 90:10) of purified lipid extract on a microporasil column (Waters Associates, Millipore Corp., Milford, MA) to achieve resolution of the $1,25(\mathrm{OH})_{2} \mathrm{D}$ produced in vitro; and $(c)$ a competitive protein-binding assay $(11,17)$ for quantifying the hormone. We confirmed adequate resolution of the reaction product by subjecting $50 \%$ of the fraction collected from the microporasil column to rechromatography over a $\mathrm{C}_{18}$-micro-Bondapak column (alcohol/water, 90:10; Waters Associates). Samples from all experimental groups subjected to repurification had measurable $1,25(\mathrm{OH})_{2} \mathrm{D}, 93.5 \pm 6.4 \%$ of that in fractions purified by the routine method and assayed. The failure of 19 nor- 10 oxo-25(OH)D to interfere with the measurement despite its apparent coelution with $1,25(\mathrm{OH})_{2} \mathrm{D}$ on the microporasil column is not surprising since this compound exhibits low crossreactivity with the binding protein used in the radioligand assay.

Biochemical determinations. Biochemical measurements were performed using previously established methods. Serum and $U_{c a}$ were analyzed using an atomic absorption spectrophotometer (model 272; Perkin-Elmer Corp., Norwalk, CT), and serum inorganic phosphorus by a colorimetric technique (18). We assayed serum $1,25(\mathrm{OH})_{2} \mathrm{D}$ in a competitive binding protein assay by a modification of previously reported methods (19). The intra- and interassay coefficients of variation of the assay averaged 7.8 and $9.6 \%$, respectively. Sensitivity of the measurement is reproducibly $2 \mathrm{pg}$, which together with the average sample recovery of $70 \%$ allows for measurement in triplicate of 12 $\mathrm{pg} / \mathrm{ml}$ of serum. $U_{\mathrm{cr}}$ was measured by enzymatic analysis using Ektachem single slide methodology (Eastman Kodak Co., Rochester, NY). iPTH was quantified by a commercially available RIA kit (Immunonuclear Corp., Stillwater, MN). The assay is a disequilibrium procedure in which an antibody developed against the 44-68 region of human PTH is used. The antibody has a well-characterized crossreactivity with a reference standard derived from rat parathyroid gland homogenates. The assay also crossreacts well with mouse PTH, allowing measurements of normal amounts in untreated mice $(61 \pm 2.3$ $\mathrm{pmol} / \mathrm{liter})$, decreased levels in calcium-loaded animals (28 \pm 3.7$)$, and elevated concentrations in vitamin D-deficient mice (116 16.7$)$.

\section{Statistical methods}

Data are expressed as mean \pm SE. We evaluated the data statistically using paired $t$ testing and analysis of variance (with appropriate a posteriori multiple range comparison procedures) (20). The adequacy of all statistical models was examined using residual plots, Bartlett's test for homogeneity of error variance, and cumulative normality probability plots.

\section{Materials}

Dr. Milan Uskokovic (Hoffman-La Roche, Nutley, NJ) kindly provided $25(\mathrm{OH}) \mathrm{D}_{3}$ for our studies. We purchased $\left[{ }^{3} \mathrm{H}\right] 1,25(\mathrm{OH})_{2} \mathrm{D}_{3}(92$ $\mathrm{Ci} / \mathrm{mmol}$ ) from Amersham Corp., Arlington Heights, IL).

\section{Results}

Renal 25(OH)D-1 $\alpha$-hydroxylase activity in normal, $G y$, and P-depleted mice

Basal function. At the time of study $G y$ and P-depleted mice had serum phosphorus concentrations of $4.7 \pm 0.3$ and $4.9 \pm 0.4$ 
$\mathrm{mg} / \mathrm{dl}$, values significantly less $(P<0.001)$ than that of normals $(8.4 \pm 0.5 \mathrm{mg} / \mathrm{dl})$, but not statistically different from each other. In contrast, the serum calcium level of $G y(8.1 \pm 0.15$ $\mathrm{mg} / \mathrm{dl})$ and normal mice $(8.3 \pm 0.16 \mathrm{mg} / \mathrm{dl})$ was significantly less $(P<0.001)$ than that of the P-depleted mice $(9.8 \pm 0.17$ $\mathrm{mg} / \mathrm{dl})$. In accord, the serum iPTH concentration was no different in the normal $(61 \pm 2.3)$ and $G y(60 \pm 2.5)$ mice, but significantly less $(P<0.05)$ in $P$-depleted animals $(45 \pm 3.5)$. Regardless, consistent with the serum phosphorus levels, $G y$ mice exhibited renal $25(\mathrm{OH}) \mathrm{D}-1 \alpha$-hydroxylase activity similar to that of P-depleted mice and significantly greater than that of normals (Fig. 1). In accord, the $G y$ and P-depleted mice manifested elevated serum $1,25(\mathrm{OH})_{2} \mathrm{D}$ levels (Fig. 1).

PTH effects. Administration of PTH (1 IU/h s.c.) to normal, Gy, and P-depleted mice resulted in significant incre-

A

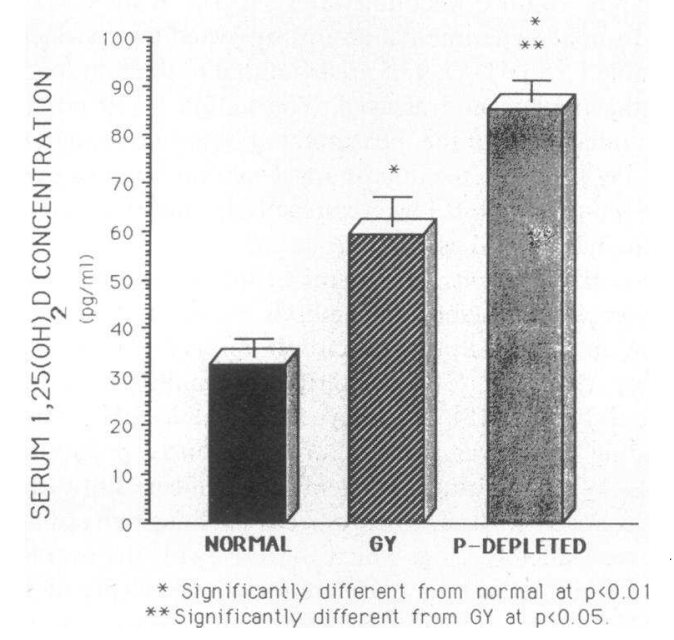

B

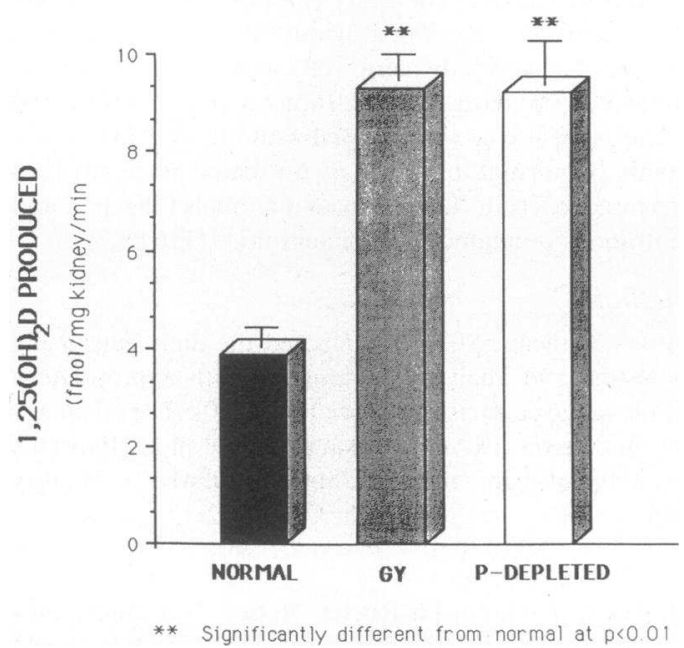

Figure 1. Regulation of vitamin D metabolism in normal, Gy, and Pdepleted mice under basal conditions. $A$, Serum $1,25(\mathrm{OH})_{2} \mathrm{D}$ concentration in pooled samples from the various animal models. Each bar represents the mean $\pm \mathrm{SE}$ of nine individual samples of $1 \mathrm{ml}$ volume. $B$, Renal 25-(OH)D-1 $\alpha$-hydroxylase activity of normal, $G y$, and $\mathrm{P}$ depleted mice. All samples were incubated for $20 \mathrm{~min}$ at $37^{\circ} \mathrm{C}$ with $80 \mu \mathrm{M} 25(\mathrm{OH}) \mathrm{D}_{3}$ provided as substrate. Each bar represents the mean $\pm \mathrm{SE}$ of at least eight individual determinations. ments of similar magnitude in the serum calcium concentrations after $24 \mathrm{~h}$ (Fig. 2). Comparable increases of iPTH to levels $>1,000$ were also observed. In contrast, the serum phosphorus level in normal and $G y$ mice decreased significantly but paradoxically increased in P-depleted animals (Fig. 2). Nevertheless, PTH administration increased enzyme activity in $G y$ mice eightfold to a level comparable to that achieved in both normal and P-depleted mice (Fig. 3).

Calcitonin effects. In further experiments administration of calcitonin (2 IU/h s.c.) to normal, $G y$, and P-depleted mice did not result in significant changes in either serum calcium or phosphorus concentrations after $24 \mathrm{~h}$. Similarly, no alterations of serum PTH from baseline levels were observed after the calcitonin infusion. However, normal, $G y$, and P-depleted mice responded to the standard calcitonin stimulus with a significant enhancement of renal $25(\mathrm{OH}) \mathrm{D}-1 \alpha$-hydroxylase activity. More importantly, the level of enzyme activity achieved after hormonal stimulation was identical in all of the animal groups (Fig. 4).

Calcium homeostasis in normal, Gy, and P-depleted mice Gastrointestinal calcium absorption. In accord with an apparent enhanced $1,25(\mathrm{OH})_{2} \mathrm{D}$ production in the basal state, $G y$

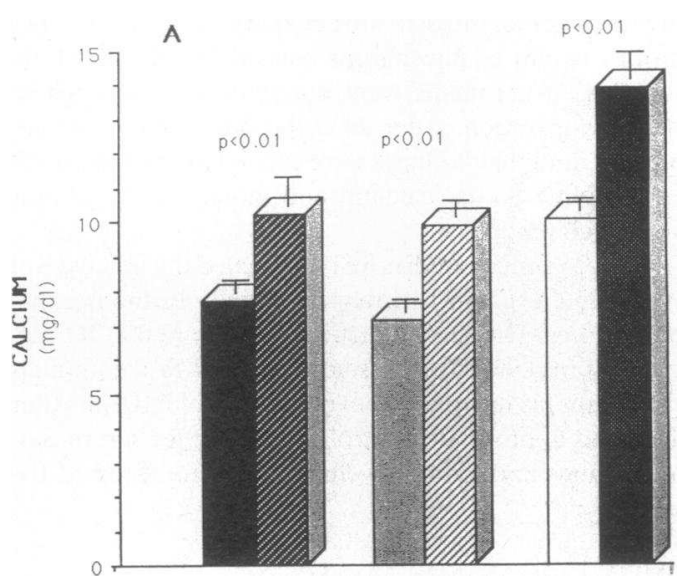

B

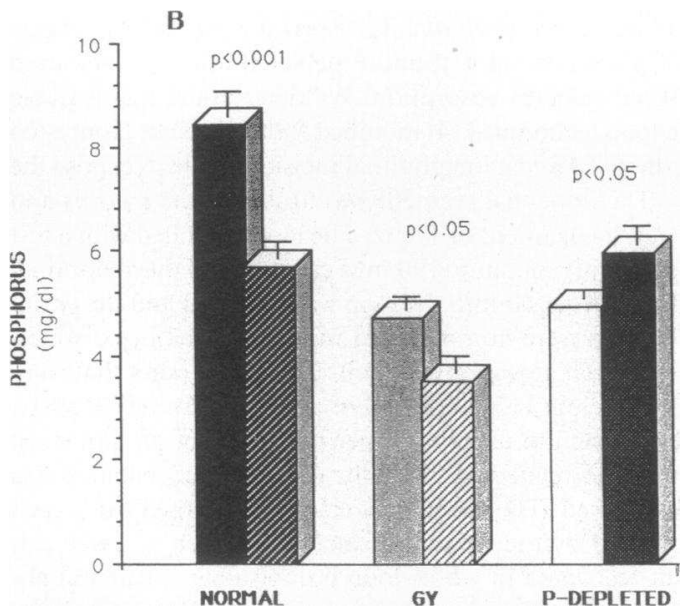

Figure 2. Serum calcium $(A)$ and inorganic phosphorus $(B)$ concentrations of normal, $G y$, and P-depleted mice before and $24 \mathrm{~h}$ after continuous subcutaneous administration of $1 \mathrm{IU} / \mathrm{h}$ parathyroid extract. In each mouse model the significance of the differences between pre- and postinfusion serum calcium and phosphorus concentrations was assessed by the paired $t$ test. Each bar represents the mean $\pm \mathrm{SE}$ of at least seven separate determinations. 


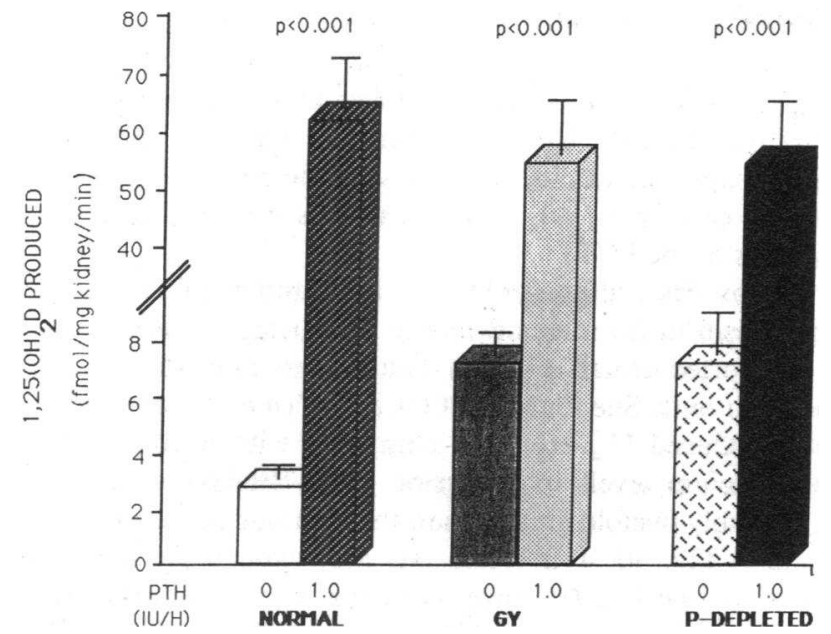

Figure 3. Renal 25(OH)D-1 $\alpha$-hydroxylase activity of normal, $G y$, and P-depleted mice after continuous subcutaneous infusion of 1 $\mathrm{IU} / \mathrm{h}$ parathyroid extract for $24 \mathrm{~h}$. All samples were incubated at $37^{\circ} \mathrm{C}$ with $80 \mu \mathrm{M} 25(\mathrm{OH}) \mathrm{D}_{3}$ provided as substrate. Data were analyzed by two-way analysis of variance and the Bonferroni multiple range comparison test. Each bar represents the mean $\pm \mathrm{SE}$ from at least seven individual determinations.

and P-depleted mice exhibited increased gastrointestinal calcium absorption compared with that in normals. Indeed, the activity maintained in the $G y$ mice $(9.9 \pm 1.5 \mathrm{mg} / \mathrm{mg}$ protein) was no different than that displayed by P-depleted animals $(9.2 \pm 0.8)$, but fully threefold greater $(P<0.01)$ than that observed in the normals $(3.2 \pm 0.1)$.

$U_{c a}$ excretion. Consistent with the increased gastrointestinal calcium absorption, $G y$ and P-depleted mice exhibited a significant elevation of $U_{c a}$ excretion compared with that of normals. In this regard the $\mathrm{U}_{\mathrm{ca}} / \mathrm{U}_{\mathrm{cr}}$ in $G y$ mice $(0.20 \pm 0.030)$ was twofold greater $(P<0.01)$ than the observed value in normals $(0.09 \pm 0.010)$ but significantly less $(P<0.05)$ than that in P-depleted mice $(0.29 \pm 0.018)$.

\section{Discussion}

The paradoxical occurrence of hypophosphatemia and normal serum calcitriol levels in patients with $\operatorname{XLH}(19,21,22)$ suggests that aberrant regulation of renal $25(\mathrm{OH}) \mathrm{D}-1 \alpha$-hydroxy-

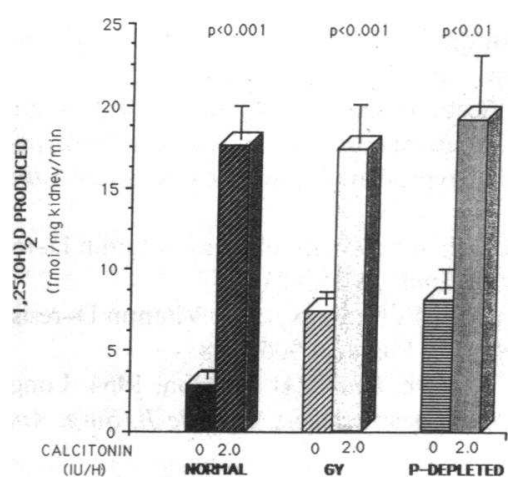

Figure 4. Renal $25(\mathrm{OH}) \mathrm{D}-1 \alpha$-hydroxylase activity of normal, $G y$, and P-depleted mice after continuous subcutaneous infusion of $2 \mathrm{IU} / \mathrm{h}$ synthetic human calciton for 24 h. All samples were incubated at $37^{\circ} \mathrm{C}$ with $80 \mu \mathrm{M} 25(\mathrm{OH}) \mathrm{D}_{3}$ provided as substrate. Data were analyzed by twoway analysis of variance and the Bonferroni multiple range comparison test. Each bar represents the mean $\pm \mathrm{SE}$ from at least five individual determinations. lase activity is a feature of this vitamin D-resistant disease. Indeed, studies in Hyp mice have established such defective regulation and indicate that the abnormal function is confined to a P/PTH-responsive enzyme that may be localized to the proximal convoluted tubule (PCT; 10, 11, 23), the site of the abnormal phosphate transport (24-26) characteristic of the disorder. While anatomic evidence for enzyme localization has not been obtained in the mouse as it has in the rat $(27,28)$ and fetal rabbit (29), these observations do suggest that the aberrant vitamin D metabolism in XLH is probably an acquired defect dependent on the disturbance in phosphate transport and consequent alterations of the intracellular milieu $(23,30)$. Therefore, the recent observation that altered renal $P$ transport in Hyp and $G y$ mice is due to independent mutations in a family of genes on the $X$ chromosome (9) raises significant questions regarding the ubiquity of the acquired defect in vitamin D metabolism in these genetic variants of the hypophosphatemic disorder.

Thus, we undertook the work documented in this report to study the regulation of renal $25(\mathrm{OH}) \mathrm{D}-1 \alpha$-hydroxylase in the $G y$ mouse. In our investigations we observed normal regulatory control of enzyme activity in these mutants. Consequently, a similar degree of phosphate deficiency (hypophosphatemia) in $G y$ and P-depleted animals under basal conditions resulted in an equivalent (approximately threefold) increment of renal $25(\mathrm{OH}) \mathrm{D}-1 \alpha$-hydroxylase above that maintained in normal mice (Fig. 1). In addition, after $24 \mathrm{~h}$ of PTH infusion (1 IU/h), kidney homogenates from $G y$ mice exhibited an increase of enzyme activity to a level no different from that attained in similarly treated normal and P-depleted animals (Fig. 3). Moreover, these PTH-mediated changes occurred in association with equivalent increments in both serum calcium (Fig. 2) and iPTH in each animal model, confirming that the observed alterations represented response to a uniform stimulus. Collectively, these data indicate that renal $25(\mathrm{OH}) \mathrm{D}-1 \alpha$-hydroxylase activity in the $G y$ mouse model of $\mathrm{XLH}$ is normally regulated by factors that probably regulate enzyme function in the PCT. These observations are in sharp contrast to those previously reported in $H y p$ mice (10-12).

However, similar to the Hyp mutant (23), Gy mice also displayed normal calcitonin regulation of enzyme activity probably localized in the proximal straight tubule. In this regard, after hormone infusion ( $2 \mathrm{IU} / \mathrm{h}$ ) for $24 \mathrm{~h}$, renal homogenates from $G y$, normal, and P-depleted mice exhibited enhancement of $25(\mathrm{OH}) \mathrm{D}-1 \alpha$-hydroxylase to equivalent levels (Fig. 4). Moreover, these changes occurred in the absence of any calcitonin-induced alteration in serum calcium, phosphorus, or iPTH, factors that might independently modulate the enzyme activity.

We confirmed the apparent normal regulation of renal $25(\mathrm{OH}) \mathrm{D}-1 \alpha$-hydroxylase in $G y$ mice by investigation of calcium homeostasis. In this regard, $G y$ mice under basal conditions maintained an elevated serum $1,25(\mathrm{OH})_{2} \mathrm{D}$ level (Fig. 1). However, the circulating concentration of this active vitamin $\mathrm{D}$ metabolite was not as great as that sustained by P-depleted animals. This difference may be due to variable $1,25(\mathrm{OH})_{2} \mathrm{D}$ metabolism in the $G y$ and P-depleted mice, or to an as yet undetermined factor. In any case, $G y$ mutants in accord manifested enhanced gastrointestinal calcium absorption, an abnormality consistent with increased $1,25(\mathrm{OH})_{2} \mathrm{D}$ production and elevated serum calcitriol levels. In fact, the observed increment of calcium absorption above normal was comparable to that in P-depleted mice in which the renal $25(\mathrm{OH}) \mathrm{D}-1 \alpha$-hy- 
droxylase and serum calcitriol were also increased. In addition, both the $G y$ and P-depleted mice displayed elevated levels of $\mathrm{U}_{\mathrm{ca}}$ excretion, changes reflecting the observed enhancement of gastrointestinal function. The greater increment in $U_{c a}$ exhibited by the P-depleted mice undoubtedly reflects the increased serum calcium concentration and suppressed iPTH levels in these animals. The failure of $G y$ mice to manifest hypercalcemia under basal conditions is probably due to osteomalacia which may influence the setting of the serum calcium level. Indeed, Hyp mice treated with pharmacological amounts of calcitriol do not develop an abnormally elevated serum calcium concentration (31-33).

The occurrence of normally regulated vitamin D metabolism in a hypophosphatemic rachitic/osteomalacic disorder is not without precedence. Liberman and his associates $(34,35)$ have recently described a new entity consisting of hereditary hypophosphatemic rickets associated with marked hypercalciuria, normocalcemia, and elevated serum $1,25(\mathrm{OH})_{2} \mathrm{D}$ levels. This phosphopenic rachitic syndrome bears remarkable similarity to the disease expressed in the $G y$ mouse. However, the genetic transmission of hypophosphatemic rickets with hypercalciuria is autosomal recessive and not $\mathrm{X}$-linked dominant. Liberman (36) has also reported the existence of a Fanconi syndrome variant in which renal phosphate wasting and hypophosphatemia occur in concert with normally regulated vitamin D metabolism. A similar association has not yet been observed in patients with a rachitic/osteomalacic disease transmitted in an X-linked dominant fashion. Heterogeneity in $\mathrm{XLH}$, however, is common. Indeed, a subgroup of affected patients with diminished hearing, a unique feature of the disease in $G y$ mice, has recently been recognized $(37,38)$. Investigation of vitamin D metabolism in these individuals has not been reported.

The pathophysiological mechanism underlying the disparate relationship between hypophosphatemia secondary to renal phosphate wasting and $1,25(\mathrm{OH})_{2} \mathrm{D}$ production in $G y$ and $H y p$ mice remains unknown. According to prevailing physiologic concepts, two alternative possibilities can be envisioned. First, the tubular locus for the defective phosphate reabsorption in both mouse models may be similar but the integrative system responsible for 1-hydroxylation of vitamin $\mathrm{D}$ is uniquely normal in the $G y$ mice. Normal calcitonin regulation of $25(\mathrm{OH}) \mathrm{D}-1 \alpha$-hydroxylase activity in Hyp mice, however, indicates that such a possibility remains unlikely. Alternately, the affected sites for the renal tubular phosphate reabsorption may be different in $H y p$ and $G y$ mice and thereby variably influence $1,25(\mathrm{OH})_{2} \mathrm{D}$ production. In this regard the selective presence of abnormal phosphate transport in the $S_{1}$ and $\mathrm{S}_{2}$ segments of the PCT in $H y p$ and $G y$ mice, respectively, can explain the inconsistent abnormality of vitamin $\mathrm{D}$ metabolism in these animal models. Such a defect in the $S_{1}$ component of the PCT in Hyp mice would directly influence or impair renal $25(\mathrm{OH}) \mathrm{D}-1 \alpha$-hydroxylase activity. In contrast, abnormal phosphate transport in $\mathrm{S}_{2}$ segments (possibly devoid of 1-hydroxylase activity) of $G y$ mice would have no direct effect on enzyme function. Rather, the loss of phosphate should result in a compensatory enhancement of phosphate flux in $S_{1}$ segments, similar to that which occurs after dietary phosphate depletion. A consequent increase in $25(\mathrm{OH}) \mathrm{D}-1 \alpha$-hydroxylase and the ability of PTH to modulate this enzyme function should ensue. While further data will be necessary to confirm this difference in the pathophysiological mechanism underlying the disease in $H y p$ and $G y$ mice, the recognition that the disorders in these animal models result from mutations of distinct members of a gene family favors the latter hypothesis. In this regard, previous studies indicate that genes within such a family, although regulating related or identical functions, may be expressed at different times during development or in different cell types (39), in this case cells from the $S_{1}$ and $S_{2}$ segments of the PCT.

In any case, although no previous studies of vitamin D metabolism in $G y$ mice have been conducted, Lyon et al. (9) have reported urinary calcium data in these mutants that contrast with ours. She found that $G y$ and $H y p$ mice have significantly reduced $U_{c a}$ excretion compared with normal. However, calcium levels in the urine of C57BL6J normals was inexplicably fivefold greater than those in our study and those of others $(29,40,41)$. While this may explain the apparent disparity regarding $G y$ mice, the equal $\mathrm{U}_{\mathrm{ca}}$ excretion of $H y p$ and $G y$ mutants, as reported by Lyon et al. (9), is irreconcilable with our observation that $H y p$ mice maintain $\mathrm{U}_{\mathrm{ca}}$ less than that of $G y$ mice and no different from that of C57BL6J normals $(0.13 \pm 0.01$ vs. $0.11 \pm 0.01)$. Whether maintaining the $G y$ mutation on a different genetic backgrounds $\left(\mathrm{B}_{6} \mathrm{C}_{3} \mathrm{H}\right.$ vs. C57BL6J) underlies these differences remains undetermined.

Regardless, we believe that our measurements of renal $25(\mathrm{OH}) \mathrm{D}-1 \alpha$-hydroxylase in $G y$ mice provide new and important data necessary to a complete understanding of the pathophysiology underlying the hypophosphatemic diseases. Indeed, our observations suggest that the phenotypic heterogeneity common to XLH may be due, in part, to genetic variability. In addition, the similarity of the autosomally transmitted human disorder hereditary hypophosphatemic rickets and hypercalciuria to the X-linked dominant disease of $G y$ mice suggests that regulation of phosphate transport along the renal PCT may be subject to a multigenic influence. We therefore postulate that the normal regulation of vitamin $\mathrm{D}$ metabolism in $G y$ mice probably results from an alteration of phosphate transport at a site in the PCT that does not negatively influence the milieu of $25(\mathrm{OH}) \mathrm{D}-1 \alpha$-hydroxylase-bearing cells.

\section{Acknowledgments}

We are indebted to Ms. Regina Whitaker for excellent technical assistance.

This study was supported in part by grants from the National Institutes of Health (AR-27032 and DK-38015) and a research grant from the National Foundation (1-852).

\section{References}

1. Albright, F., A. M. Butler, and E. Bloomberg. 1937. Rickets resistant to vitamin D therapy. Am. J. Dis. Child. 54:529-547.

2. Stickler, G. B., J. W. Beabout, and B. L. Riggs. 1970. Vitamin D-resistant rickets: clinical experience with 41 typical familial hypophosphatemic patients and 2 atypical nonfamilial cases. Mayo Clin. Proc. 45:197-204.

3. Stickler, G. B. 1969. Familial hypophosphatemic vitamin D-resistant rickets. Acta Paediatr. Scand. 58:213-219.

4. Tapia, J., G. Stearns, and I. V. Ponsetti. 1964. Vitamin D-resistant rickets. J. Bone Jt. Surg. Am. Vol. 46A:935-958.

5. Pierce, D. S., W. M. Wallace, and C. H. Herdon. 1964. Longterm treatment of vitamin D-resistant rickets. J. Bone Jt. Surg. Am. Vol. 46A:979-997.

6. Burnett, C. H., C. E. Dent, C. Harper, and B. J. Warland. 1964. Vitamin D-resistant rickets: analysis of 24 pedigrees with hereditary and sporadic cases. Am. J. Med. 36:222-232. 
7. Briard-Guillenot, M. L., E. Raverdy, S. Balsan, J. Rey, and J. Frezal. 1972. Etude critique de l'hypophosphatemie pour l'etude genetique du rachitisme vitamino-resistant hypophosphatemique familial. Arch. Fr. Pediatr. 29:1059-1064.

8. Rasmussen, H., and C. Anast. 1983. Familial hypophosphatemic (vitamin D-resistant) rickets. In The Metabolic Basis of Inherited Disease. J. B. Stanbury, J. B. Wyngaarden, D. S. Fredrickson, J. L. Goldstein, and M. S. Brown, editors. McGraw-Hill Inc., New York. 1751-1764.

9. Lyon, M. F., C. R. Scriver, L. R. I. Baker, H. S. Tenenhouse, J. Kronick, and S. Mandla. 1986. The $G y$ mutation: another cause of X-linked hypophosphatemia in mouse. Proc. Natl. Acad. Sci. USA. 83:4899-4903.

10. Nesbitt, T., M. K. Drezner, and B. Lobaugh. 1986. Abnormal parathyroid hormone stimulation of 25-hydroxyvitamin D-1 $\alpha$-hydroxylase activity in the hypophosphatemic mouse. Evidence for a generalized defect of vitamin D metabolism. J. Clin. Invest. 77:181187.

11. Lobaugh, B., and M. K. Drezner. 1983. Abnormal regulation of renal 25 -hydroxyvitamin $\mathrm{D}$-1 $\alpha$-hydroxylase activity in the $\mathrm{X}$-linked hypophosphatemic mouse. J. Clin. Invest. 71:400-403.

12. Tenenhouse, $H$. S. 1984. Investigation of the mechanism for abnormal renal 25-hydroxyvitamin $\mathrm{D}_{3}-1$-hydroxylase activity in $\mathrm{X}$ linked hyp mouse. Endocrinology. 115:634-639.

13. Yamaoka, K., Y. Seino, K. Satomura, Y. Tanaka, H. Yabuuchi, and M. R. Haussler. 1986. Abnormal relationship between serum phosphate concentration and renal 25-hydroxycholecalciferol-1-hydroxylase activity in X-linked hypophosphatemic mice. Miner. Electrolyte Metab. 12:194-198.

14. Dostal, L. A., and S. U. Toverud. 1984. Effect of vitamin $D_{3}$ on duodenal calcium absorption in vivo during early development. Am. J. Physiol. 246:G528-G534.

15. Sarkar, B. C. R., and U. P. S. Chauhan. 1967. A new method for determining micro quantities of calcium in biological materials. Anal. Biochem. 20:155-166.

16. Lowry, O. H., N. J. Rosebrough, A. L. Farr, and R. J. Randall. 1951. Protein measurement with the Folin phenol reagent. J. Biol. Chem. 193:265-275.

17. Lobaugh, B., and M. K. Drezner. 1983. Measurement of 25hydroxyvitamin D-1 $\alpha$ hydroxylase activity in mamalian kidney. Anal. Biochem. 129:416-424.

18. Dryer, R. L., A. R. Tammes, and J. I. Routh. 1957. The determination of phosphorus and phosphatase with $n$-phenyl-p-phenylendiamine. J. Biol. Chem. 225:177-183.

19. Lyles, K. W., A. G. Clark, and M. K. Drezner. 1982. Serum 1,25-dihydroxyvitamin $\mathrm{D}$ levels in subjects with $\mathrm{X}$-linked hypophosphatemic rickets and osteomalacia. Calcif. Tissue Int. 34:125-130.

20. Neter, J., and W. Wasserman. 1974. Applied Linear Statistical Models. R. D. Irwin, Inc., Hanswerd, IL.

21. Scriver, C. R., T. M. Reade, H. F. DeLuca, and A. J. Hamstra. 1978. Serum 1,25 dihydroxyvitamin D levels in normal subjects and in patients with hereditary rickets or bone disease. N. Engl. J. Med. 299:976-979.

22. Chesney, R. W., R. B. Mazess, P. Rose, and H. F. DeLuca 1980. Supranormal 25-hydroxyvitamin $D$ and subnormal 1,25-dihydroxyvitamin D: their role in X-linked hypophosphatemic rickets. $\mathrm{Am}$. J. Dis. Child. 134:140-143.

23. Nesbitt, T., B. Lobaugh, and M. K. Drezner. 1987. Calcitonin stimulation of renal 25 -hydroxyvitamin- $1 \alpha$-hydroxylase activity in hypophosphatemic mice. Evidence that the regulation of calcitriol production in not universally abnormal in X-linked hypophosphatemia. J. Clin. Invest. 79:15-19.

24. Cowgill, L. D., S. Goldfarb, K. Lau, E. Slatopolsky, and Z. S. Agus. 1979. Evidence for an intrinsic renal tubular defect in mice with genetic hypophosphatemic rickets. J. Clin. Invest. 63:1203-1210.
25. Giasson, S. D., M. G. Brunette, G. Danan, N. Vigneault, and S. Carrier. 1977. Micropuncture study of renal phosphorus transport in hypophosphatemic vitamin D resistant rickets mice. Pfluegers Arch. Eur. J. Physiol. 371:33-38.

26. Tenenhouse, H. S., C. R. Scriver, R. R. McInnes, and F. H. Glorieux. 1978. Renal handling of phosphate in vivo and in vitro by the X-linked hypophosphatemic male mouse: evidence for a defect in the brush border membrane. Kidney Int. 14:236-244.

27. Kawashima, H., S. Torikai, and K. Kurokawa. 1981. Calcitonin selectively stimulates 25 -hydroxyvitamin $D_{3}-1 \alpha$-hydroxylase in the proximal straight tubule of the rat kidney. Nature (Lond.). 291:327-329.

28. Kawashima, H., and K. Kurokawa. 1983. Unique hormonal regulation of vitamin D metabolism in the mammalian kidney. Miner. Electrolyte Metab. 9:227-235.

29. Akiba, T., H. Endou, C. Koseki, F. Sakai, N. Horiuchi, and T. Suda. 1980. Localization of 25 -hydroxyvitamin $\mathrm{D}_{3}-1 \alpha$-hydroxylase activity in the mammalian kidney. Biochem. Biophys. Res. Commun. 94:313-318.

30. Nesbitt, T., G. A. Davidai, and M. K. Drezner. 1989. Abnormal adenosine $3^{\prime}, 5^{\prime}$-monophosphate stimulation of renal 1,25-dihydroxyvitamin D production in $H y p$-mice: evidence that 25 -hydroxyvitamin D- $1 \alpha$-hydroxylase dysfunction results from aberrant intracellular function. Endocrinology. 124:1184-1189.

31. Tenenhouse, H. S., and C. R. Scriver. 1981. Effect of 1,25-dihydroxyvitamin $\mathrm{D}_{3}$ on phosphate homeostasis in the X-linked hypophosphatemic (hyp) mouse. Endocrinology. 109:658-660.

32. Kurose, H., K. Yamaoka, Y. Tanaka, T. Ishii, M. Ishida, Y. Seino, and $H$. Yabuuchi. 1982. Effect of $1,25(\mathrm{OH})_{2} \mathrm{D}_{3}$ and $1,24(\mathrm{R})(\mathrm{OH})_{2} \mathrm{D}_{3}$ on the $\mathrm{X}$-linked hypophosphatemic mouse. In Vitamin D, Chemical, Biochemical and Clinical Endocrinology of Calcium Metabolism. A. W. Norman, K. Schaefer, H. G. Grigoleit, and D. V. Herrath, editors. Walter de Gruyter \& Co., Berlin, FRG. 397-399.

33. Marie, P. J., R. Travers, and F. H. Glorieux. 1982. Bone response to phosphate and vitamin D metabolites in the hypophosphatemic male mouse. Calcif. Tissue Int. 34:158-164.

34. Tieder, M., D. Modai, R. Samuel, R. Arie, A. Halabe, I. Bab, D. Gabizon, and U. Liberman. 1985. Hereditary hypophosphatemic rickets with hypercalciuria. N. Engl. J. Med. 312:611-617.

35. Tieder, M., D. Modai, U. Shaked, R. Samuel, R. Arie, A. Halabe, J. Maor, J. Weissgarten, Z. Averbukh, N. Cohen, S. Edelstein, and U. A. Liberman. 1987. Idiopathic hypercalciuria and hereditary hypophosphatemic rickets: two phenotypical expressions of a common genetic defect. $N$. Engl. J. Med. 316:125-129.

36. Tieder, M., R. Arie, D. Modai, R. Samuel, J. Weissgarten, and U. A. Liberman. 1988. Elevated serum 1,25-dihydroxyvitamin D concentrations in siblings with primary Fanconi's syndrome. $N$. Engl. J. Med. 319:845-848.

37. Boneh, A., T. M. Reade, C. R. Scriver, and E. Rishikof. 1987. Audiometric evidence for two forms of X-linked hypophosphatemia in humans, apparent counterparts of $H y p$ and $G y$ mutations in mouse. Am. J. Med. Genet. 27:997-1003.

38. Davies, M., R. Kane, and J. Valentine. 1984. Impaired hearing in X-linked hypophosphatemic (vitamin-D-resistant) osteomalacia. Ann. Intern. Med. 100:230-232.

39. Lewin, B. 1987. Genes III. John Wiley \& Sons, New York. 399-419.

40. Seino, Y., K. Yamaoka, M. Ishida, Y. Tanaka, H. Kurose, H. Yabuuchi, Y. Toshira, M. Furushima, and Y. Nishii. 1982. Plasma clearance, for high doses of exogenous 1,25 -dihydroxy $\left[23,24(n)-{ }^{3} \mathrm{H}\right]$ cholecalciferol in X-linked hypophosphatemic mice. Biomed. Res. 3:683-687.

41. Crocker, J. F. S., S. F. Muhtadie, D. C. Hamilton, and D. E. C. Cole. 1985. The comparative toxicity of vitamin D metabolites in the weanling mouse. Toxicol. Appl. Pharmacol. 80:119-126. 